\title{
Hubungan Literasi Media Sosial Pustakawan Perguruan Tinggi dengan Kualitas Pemanfaatan e-Resources Perpustakaan
}

\author{
Fidan Safira $^{1^{*}}$; Indira Irawati ${ }^{1}$ \\ ${ }^{1}$ Departemen Ilmu Perpustakaan dan Informasi, Fakultas Ilmu Budaya, Universitas Indonesia \\ *Korespondensi: fidansafira19@gmail.com
}

\begin{abstract}
Information flooding in social media does not always provide accurate information. The ability to search, select, sort and use digital information is called media literacy. Librarians is an intermediary gateway for accurate information. So, they need to have appropriate media literacy skills to produce quality information. This study aims to determine the relationship between social media literacy and the quality of e-resources being use. Three aspects of social media literacy theorywas employed: technical ability, cognitive ability and affective ability. The concept of the quality of the use of e-resources includes five aspects: currency, relevance, authority, accuracy and purpose. The respondents of this study were 65 college librarians from a total population of 645 librarians. The results of this study state that all variables have a strong relationship. The correlation value is 0.684 . But, the correlation technical ability with the quality of e-resources use is weak, which was shown by the value 0.170.
\end{abstract}

Keywords: social media literacy; information quality; e-reseources

\begin{abstract}
Abstrak
Fenomena banjir informasi dalam media sosial tidak selalu menyediakan informasi yang akurat. Kemampuan dalam mencari, memilih, memilah dan menggunakan informasi dalam dunia digital disebut sebagai literasi media. Kemampuan literasi media yang baik sangat berpotensi menghasilkan informasi yang berkualitas. Penelitian ini bertujuan untuk mengetahui keeratan hubungan antara variabel literasi media sosial dengan variabel kualitas pemanfaatan e-resources. Acuan teori yang digunakan dalam penelitian, yaitu literasi media sosial terdiri dari tiga aspek kemampuan, yaitu kemampuan teknis, kemampuan kognitif dan kemampuan afektif. Serta konsep kualitas pemanfaatan e-resources yang mencakup lima aspek yaitu: pemahaman kemutakhiran informasi (currency), pemahaman kesesuaian informasi (relevancy), pemahaman kepemilikan informasi (authority), pemahaman ketepatan informasi (accuracy) dan yang terakhir adalah pemahaman alasan publikasi informasi (purpose). Adapun responden penelitian ini adalah 65 pustakawan perguruan tinggi dari total populasi sebesar 645 pustakawan. Hasil penelitian ini menunjukan bahwasannya keseluruhan variabel memiliki hubungan yang cukup kuat antara variabel literasi media sosial dengan variabel kualitas pemanfaatan e-resources dengan nilai korelasi sebesar 0,684. Meskipun nilai korelasi antara kemampuan teknis dengan variabel kualitas pemanfaatan eresources hanya 0,170 yang artinya memiliki yang sangat lemah.
\end{abstract}

Kata Kunci: literasi media sosial; kualitas pemanfaatan informasi; e-resources

\section{PENDAHULUAN}

Perkembangan teknologi informasi berdampak sangat massive pada hampir seluruh aspek kehidupan manusia. Terlebih kemudahan dalam menemukan informasi yang dibutuhkan. Penggunaan teknologi informasi, seperti gadget, laptop dan tablet menjadi sangat membantu manusia untuk memenuhi kebutuhan informasinya. Cukup dengan genggaman, informasi sudah didapatkan. Lebih dari itu, masyarakat tidak hanya dapat mengakses informasi. Masyarakat juga dapat melakukan sharing informasi melalui media sosial, seperti twitter, instagram, dan Facebook. Konsep sharing, posting dan comment ini membuat sangat terbukanya argumen berakibat pada banyaknya data yang tersebar pada dunia digital.

Fenomena yang disebut big data ini merupakan “...an evolving term that describes any voluminous amount of structured, semistructured and unstructured data that has the potential to be mined for information" (Nath, 2015). Big data menghasilkan data yang sangat besar dan banyak secara kuantitas (volume), variatif (bentuk, ukuran dan format) dan percepatan (tingkat 
pertumbuhan data). Besarnya data dari berbagai bidang yang tersebar di dunia digital menjadikan banjir arus informasi. Banjir informasi menyulitkan khalayak untuk menentukan informasi yang benar dengan informasi palsu. Saat ini, pemberitaan palsu (hoax) menjadi fokus perhatian terutama di media online (Gumilar, 2017).

Media sosial merupakan sebuah sarana komunikasi yang dapat digunakan sebagai tempat untuk mencari sumber-sumber informasi dan dalam penggunaaanya diperlukan keterampilan literasi media (Kurnia, 2018). Saat ini peranan media sosial menjadi sangat dekat dengan kehidupan masyarakat. Tidak sedikit masyarakat yang merasa tidak bisa lepas dari media sosial. Lebih lanjut, menurut Aljawiy, (2012) media sosial memiliki dampak baik positif maupun negatif. Dampak positifnya meliputi: kemudahan berinteraksi dan berkomunikasi, sebagai sarana promosi dan sosialisasi serta sebagai sarana hiburan. Sedangkan dampak negatifnya meliputi: tergantikannya kehidupan sosial semestinya, pemborosan, kecanduan, pornografi dan dampak bagi kesehatan. Guna menghindari dampak negatif tersebut, pengguna media sosial harus dibekali kemampuan literasi media sosial.

Kemampuan untuk memilih dan memilah informasi yang tepat dan sesuai pada media sosial dibutuhkan kemampuan literasi media sosial. Literasi media sosial bertujuan untuk "covers the interpretation of people's active participation in communicating, selecting, creating, critiquing and sharing media content on the Internet" (Vanwynsberghe, 2015). Lebih lanjut, literasi media sosial ini menunjukan kemampuan dalam menyaring informasi yang ditemukan melalui media sosial serta penggunaannya untuk hal-hal yang bermanfaat bagi kehidupan penggunanya. Pemanfaatan media sosial yang sehat dimulai dengan literasi media sosial dari pengguna media sosial. Kemampuan literasi media sosial ini menjadi penting terutama bagi profesi pustakawan. Pustakawan memiliki peran penting dalam menyediakan informasi yang relevan. Selain media sosial, pustakawan yang bekerja pada institusi informasi dan ilmu pengetahuan tentu harus memiliki kemampuan menggunakan sumber informasi lain, seperti melalui pemanfaatan koleksi referensi yang tersedia di perpustakaan. Hal tersebut guna mendapatkan informasi yang relevan dan akurat.

Hakekatnya, setiap perpustakaan memiliki koleksi referensi yang mendukung pemenuhan kebutuhan informasi pemustakanya. Perkembangan teknologi pun berdampak pada kemudahan akses informasi masyarakat. Begitu pula dengan koleksi referensi yang mulai beragam, baik tercetak maupun elektronik. Koleksi referensi elektronik atau e-resources saat ini telah banyak dilanggan oleh perpustakaan perguruan tinggi dengan mengikuti prinsip big data, yaitu volume data yang besar, variety dari berbagai bidang ilmu pengetahuan serta velocity yang cepat. Koleksi e-resources dalam Nurmalia, (2016) merupakan salah satu layanan koleksi utama perpustakaan yang memanfaatkan teknologi informasi dan internet untuk memenuhi kebutuhan informasi pemustaka. Penggunaan e-resources di perpustakaan tidak terlepas dari peran dan kompetensi pustakawan perguruan tinggi.

Penelitian yang dilakukan oleh Nurjanah, dkk (2017) mengenai hubungan antara literasi digital dengan kualitas penggunaan e-resources pada mahasiswa Fakultas Kedokteran Gigi Universitas Padjadjaran. Penelitian ini menggunakan metode kuantitatif dengan pendekatan korelasional yaitu untuk mengetahui ada dan tidaknya hubungan antara dua variabel atau lebih dan seberapa tingkat hubungannya. Penelitian ini menunjukkan bahwa literasi digital memiliki hubungan yang signifikan dengan kualitas penggunaan e-resources, dengan kategori very high correlation, artinya literasi digital menjadi faktor yang sangat menentukan terhadap tingginya kualitas penggunaan e-resources. Lebih lanjut, penelitian serupa juga pernah dilakukan oleh Kurnia, dkk (2018) dengan judul Hubungan Pemanfaatan Media Sosial Instagram Dengan Kemampuan Literasi Media di UPT Perpustakaan Itenas. Hasil penelitian ini menunjukkan bahwa terdapat hubungan yang kuat dan signifikan antara pemanfaatan media sosial instagram dan 
kemampuan literasi media. Secara khusus hasil penelitian menunjukkan bahwa gambaran pemanfaatan media sosial instagram berada pada kategori sangat baik dan gambaran kemampuan literasi media berada pada kategori sangat baik.

Selanjutnya, penelitian ini bertujuan untuk mengetahui hubungan antara variable literasi media sosial dengan variable kualitas pemanfaatan e-resources pada pustakawan yang bekerja di perpustakaan perguruan tinggi. Peran pustakawan disini menjadi sangat krusial dalam menyediakan sumber-sumber yang berkualitas dalam layanan referensi. Sehingga kemampuan dalam literasi media sosial pustakawan perguruan tinggi diasumsikan berpengaruh. Berdasarkan pemaparan tersebut, artikel ini ingin melihat bagaimana hubungan literasi media sosial dengan kualitas pemanfaatan e-resources oleh pustakawan. Hipotesis pada penelitian ini yaitu $\mathrm{H} 0$ adanya hubungan literasi media sosial dengan kualitas pemanfaatan e-resources dan H1 tidak adanya hubungan literasi media sosial dengan kualitas pemanfaatan e-resources.

\section{METODE PENELITIAN}

Penelitian ini menggunakan jenis penelitian korelasional dengan pendekatan kuantitatif. Penelitian korelasional bertujuan untuk mengetahui ada dan tidaknya hubungan antara dua variabel atau lebih dan bagaimana hubungan antaran variable tersebut. Sebagaimana tujuan penelitian ini adalah untuk mengetahui adanya hubungan literasi media sosial dengan pemanfaatan e-resources oleh pustakawan perguruan tinggi. Penelitian ini dilakukan pada Bulan April 2019. Metode pengumpulan data yang digunakan adalah survey online kepada 65 sampel dengan teknik random sampling dari total populasi pustakawan di perpustakaan perguruan tinggi sebanyak 645 orang (Perpustakaan Nasional, 2018). Metode sampling menggunakan teori probabilitas sampling, dimana setiap populasi memiliki kesempatan yang sama menjadi sampel penelitian. Arikunto (2010) menjelaskan bahwa, jika subjeknya kurang dari 100 orang sebaiknya diambil semuanya, jika subjeknya lebih dari 100 orang dapat diambil $10-15 \%$ atau $20-25 \%$ atau lebih. Mengacu pada pendapat tersebut, penelitian ini menggunakan sampel sebesar $10 \%$ dari total populasi dengan derajat kepercayaan sebesar 12\%. Semakin besar derajat kepercayaan menunjukkan semakin kecil jumlah sampel. Selain itu juga menunjukkan bahwa penelitian ini tidak dapat digeneralisasi.

Definisi operasional variable dalam penelitian ini adalah variable $\mathrm{X}$ yaitu literasi media sosial dan variable $\mathrm{Y}$ kualitas pemanfaatan e-resources. Variabel $\mathrm{X}$ memiliki 3 indikator berdasarkan konsep literasi sosial media menurut Vanwynsberghe and Verdegem, (2013), yaitu: kompetensi teknis, kompetensi kognitif dan kompetensi afektif. Sedangkan variable Y memiliki lima indikator berdasarkan konsep evaluasi kualitas pemanfaatan e-resources menurut Meriam Library, (2010), yaitu: pemahaman kemutakhiran informasi (currency), pemahaman kesesuaian informasi (relevancy), pemahaman kepemilikan informasi (authority), pemahaman ketepatan informasi (accuracy) dan yang terakhir adalah pemahaman alasan publikasi informasi (purpose). Selanjutnya, pengolahan data dalam penelitian ini menggunakan aplikasi SPSS 21, yang meliputi uji validitas, uji reabilitas, uji asumsi klasik, dan uji korelasional bivariate. Sedangkan analisa data menggunakan analisa data deskriptif.

\section{HASIL DAN PEMBAHASAN}

Penelitian ini menggunakan populasi pustakawan perguruan tinggi sebanyak 645 orang berdasarkan data dari perpustakaan nasional, 2018. Sehingga, sampel yang digunakan sebanyak $10 \%$ dari populasi sehingga sebesar 65 responden. Adapun gambaran umum responden berdasarkan karakteristik sebagai berikut: 
Tabel 1

Gambaran Umum Responden Berdasarkan Jenis Kelamin

\begin{tabular}{cc}
\hline Jenis Kelamin & Jumlah Responden \\
\hline Laki-laki & 16 \\
Perempuan & 49 \\
\hline
\end{tabular}

Sumber: Hasil Olahan Penulis, 2019

Berdasarkan tabel 1 terlihat sebagian besar responden berjenis kelamin perempuan dengan prosentase sebesar $24,6 \%$ dan responden yang berjenis kelamin laki-laki dengan prosentase sebesar 75,4\%. Kemudian berdasarkan jenjang usia bisa dilihat pada tabel 2 .

Tabel 2

Gambaran Umum Responden Berdasarkan Usia

\begin{tabular}{cc}
\hline Usia & Jumlah \\
\hline Kurang dari 25 Tahun & 22 \\
26-35 Tahun & 31 \\
36-45 Tahun & 8 \\
Lebih dari 45 Tahun & 4 \\
\hline Sumber: Hasil Olahan Penulis, 2019
\end{tabular}

Berdasarkan tabel 2 prosentase responden yang berusia kurang dari 25 tahun sebesar 33,8\%, responden yang berusia antara 26-35 tahun sebesar 47,7\%, responden yang berusia 36-45 tahun sebesar $12,3 \%$ dan responden yang berusia lebih dari 45 tahun sebesar 6,2\% dari total responden. Lebih lanjut, jenjang pendidikan responden dapat dilihat berdasarkan tabel 3.

Tabel 3

Gambaran Umum Responden Berdasarkan Jenjang Pendidikan

\begin{tabular}{cc}
\hline Jenjang Pendidikan & Jumlah \\
\hline Diploma & 1 \\
Sarjana & 59 \\
Magister & 5 \\
\hline
\end{tabular}

Sumber: Hasil Olahan Penulis, 2019

Berdasarkan tabel 3 jumlah responden yang memiliki jenjang pendidika terakhir SMA dan Diploma masing-masing satu orang. Sedangkan responden yang memiliki jenjang pendidikan terakhir sarjana sebesar 89,2\% dari total responden dan yang memiliki jenjang pendidikan terakhir magister sebesar $7,7 \%$ dari total responden.

\section{Uji Validitas dan Reabilitas}

Uji validitas merupakan upaya pengukuran yang menunjukkan tingkat kevalidan suatu instrument. Variabel dapat dikatakan mempunyai validitas jika memenuhi standar kevalidan, begitu pula sebaliknya. Langkah-langkah pengujian validitas adalah mendefinisikan secara operasional konsep yang akan diukur, melakukan uji coba skala pengukuran tersebut pada sejumlah responden. Uji validitas dalam penelitian ini menghasilkan $r$ hitung ditampilkan dalam tabel 4 . 
Tabel 4

Uji Validitas Variabel X

\begin{tabular}{cccc}
\hline Item & R Hitung & R Tabel & Kesimpulan \\
\hline X1.1 & 0,280 & 0,2423 & Valid \\
X2.1 & 0,532 & 0,2423 & Valid \\
X2.2 & 0,442 & 0,2423 & Valid \\
X2.3 & 0,592 & 0,2423 & Valid \\
X2.4 & 0,712 & 0,2423 & Valid \\
X3.1 & 0,409 & 0,2423 & Valid \\
X3.2 & 0,566 & 0,2423 & Valid \\
X3.3 & 0,606 & 0,2423 & Valid \\
X3.4 & 0,263 & 0,2423 & Valid \\
\hline
\end{tabular}

Sumber: Hasil Olahan Penulis, 2019

Berdasarkan tabel 4, keseluruhan pertanyaan yang diajukan dalam penelitian ini valid. Selanjutnya adalah uji validitas untuk variable Y dapat dilihat dalam tabel 5.

Tabel 5

Uji Validitas Variabel Y

\begin{tabular}{cccc}
\hline Item & R Hitung & R Tabel & Kesimpulan \\
\hline Y1.1 & 0,638 & 0,2423 & Valid \\
Y1.2 & 0,676 & 0,2423 & Valid \\
Y1.3 & 0,608 & 0,2423 & Valid \\
Y2.1 & 0,718 & 0,2423 & Valid \\
Y2.2 & 0,656 & 0,2423 & Valid \\
Y3.1 & 0,724 & 0,2423 & Valid \\
Y3.2 & 0,651 & 0,2423 & Valid \\
Y3.3 & 0,704 & 0,2423 & Valid \\
Y3.4 & 0,502 & 0,2423 & Valid \\
Y4.1 & 0,735 & 0,2423 & Valid \\
Y4.2 & 0,503 & 0,2423 & Valid \\
Y4.3 & 0,592 & 0,2423 & Valid \\
Y5.1 & 0,702 & 0,2423 & Valid \\
Y5.2 & 0,704 & 0,2423 & Valid
\end{tabular}

Begitu pula dengan hasil uji validitas pada variable Y yang secara keseluruhan pertanyaan dalam penelitian ini valid.

Uji reabilitasnya merupakan pengujian untuk mengetahui apakah alat pengukuran mempunyai kehandalan dalam mengukur. Apabila Reliability coefficient (alpha cronbach's) nilainya > 0,60 maka variabel dan butir pertanyaan yang diukur dapat dipercaya atau diandalkan (Sunyoto, 2007 : 107). Berdasarkan uji reabilitas menunjukkan $\alpha$ variable X sebesar 11 yang berarti realible dan $\alpha$ variable Y sebesar 15 yang bernilai juga reliable. Berdasarkan data tersebut dapat dilihat bahwasannya baik variable $\mathrm{X}$ maupun variable $\mathrm{Y}$ sudah memenuhi standart kevalidan. Begitu pula dengan alat pengukur yang digunakan dalam penelitian ini pun sudah terbukti memiliki kehandalan untuk mengukur.

\section{Uji Asumsi Klasik}

Menurut Rosita, (2012) uji asumsi klasik adalah untuk memberikan kepastian bahwa persamaan regresi yang didapatkan memiliki ketepatan dalam estimasi, tidak bias dan konsisten. Uji asumsi klasik memiliki beberapa tahapan, yaitu: uji asumsi multikolinearitas, uji autokorelasi, uji heterokedasitas, uji normalitas dan uji linearitas. Berdasarkan hal tersebut, uji asumsi klasik dalam penelitian ini untuk mengetahui hubungan antara variable literasi sosial media dengan 
pemanfaatan kualitas informasi e-resources, sehingga hanya menggunakan dua tahapan uji asumsi klasik, yaitu uji normalitas dan uji linearitas. Adapun hasil pengujian tersebut sebagai berikut:

\section{Uji normalitas}

Uji normalitas adalah untuk menguji apakah dalam sebuah model regresi, variabel independen, variabel dependen, atau keduanya mempunyai distribusi normal atau tidak. Suatu model regresi yang baik adalah yang memiliki distribusi data normal atau mendekati normal (Rosita, 2012).

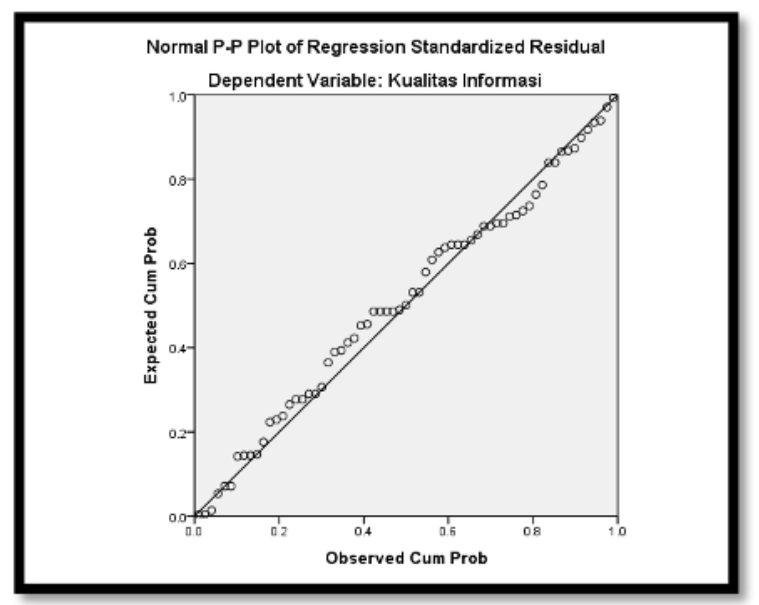

Gambar 1.

Uji Normalitas

Sumber: Hasil Olahan Penulis, 2019

Berdasarkan gambar 1 dapat dilihat bahwasannya pada grafik normal plot, terlihat titik-titik menyebar disekitar garis diagonal. Pada grafik tersebut menunjukkan bahwa model regresi tidak menyalahi asumsi normalitas. Jadi dapat disimpulkan bahwa model regresi pada penelitian ini memenuhi syarat untuk menjadi model regresi yang baik karena merupakan model regresi yang memiliki distribusi data normal atau mendekati normal.

\section{Uji linearitas}

Uji linieritas dilakukan dengan melihat scatterplot antara standar residual dengan prediksinya (Roosita, 2012). Bila sebaran tidak menunjukkan pola tertentu maka dikatakan asumsi linieritas memenuhi syarat. Gambar berikut merupakan hasil dari uji linearitas penelitian ini:

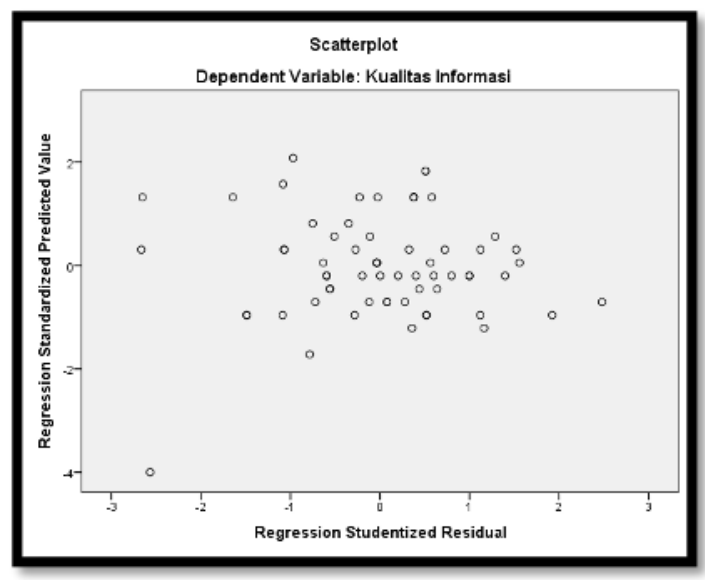

Gambar 2.

Uji Linearitas

Sumber: Hasil Olahan Penulis, 2019 
Berdasarkan gambar 2 terlihat hasil pengujian menunjukkan scatterplot tidak membentuk pola tertentu sehingga dapat disimpulkan bahwa model pada penelitian ini memenuhi syarat untuk menjadi model yang baik karena asumsi linieritas terpenuhi.

\section{Uji Korelasi}

Uji korelasi dilakukan untuk mengetahui hubungan antara satu variable dengan satu variabel lain (Muhson, 2013). Penelitian ini menguji dua variable yaitu variable $\mathrm{X}$, yaitu literasi media sosial dengan variable $\mathrm{Y}$, yaitu kualitas pemanfaatan e-resources. Berdasarkan pengujian tersebut, di dapatkan hasil pearson correlation sebagai berikut:

Tabel 7

Hasil Uji Korelasi

\begin{tabular}{cc}
\hline Item & Pearson Corellation/ r Hitung \\
\hline $\mathrm{X}$ & 0,684 \\
$\mathrm{Y}$ & 0,684 \\
\hline \multicolumn{2}{c}{ Sumber: Hasil Olahan Penulis, 2019}
\end{tabular}

Sumber: Hasil Olahan Penulis, 2019

Berdasarkan tabel 7 dapat dilihat bahwasannya nilai korelasi varibel X dan Y sebesar 0,684. Berdasarkan prinsip korelasi, apabila $\mathrm{r}$ hitung > dari pada $\mathrm{r}$ tabel maka terdapat korelasi atau hubungan antara variable $\mathrm{X}$ dan $\mathrm{Y}$. Nilai $\mathrm{r}$ hitung pada tabel tersebut adalah 0,684 dan nilai $\mathrm{r}$ tabel dengan jumlah sampel N-2 adalah 0,2058. Sehingga dapat disimpulkan hasil $r$ hitung $>r$ tabel, maka terdapat hubungan atau korelasi antara variable $\mathrm{X}$, yaitu literasi media sosial dengan variable Y, yaitu kualitas pemanfaatan e-resources. Sehingga, H0 dalam penelitian ini diterima dan $\mathrm{H} 1$ ditolak.

\section{Hubungan Literasi Media Sosial dengan Kualitas Pemanfaatan E-Resources}

Wilson dalam Yusup \& Subekti (2010) menyatakan bahwa dalam melakukan pencarian informasinya individu akan berinteraksi atau menggunakan sistem pencarian manual melalui media tekstual atau menggunakan media berbasis komputer. Kemampuan literasi pengguna informasi akan menghasilkan informasi yang berkualitas. Literasi media sosial sebagai kemampuan yang harus dimiliki oleh pustakawan dalam mencari, memilih, memilah dan menggunakan informasi di media sosial. Sebagaimana teori yang menjadi acuan dalam penelitian ini, literasi media sosial terdiri dari tiga aspek kemampuan, yaitu kemampuan teknis, kemampuan kognitif dan kemampuan afektif. Serta konsep kualitas pemanfaatan e-resources yang mencakup lima aspek yaitu: pemahaman kemutakhiran informasi (currency), pemahaman kesesuaian informasi (relevancy), pemahaman kepemilikan informasi (authority), pemahaman ketepatan informasi (accuracy) dan yang terakhir adalah pemahaman alasan publikasi informasi (purpose). 1.Hubungan Kemampuan Teknis dengan Kualitas Pemanfaatan E-Resources

Nilai $\mathrm{r}$ hitung diketahui sebesar 0,170 dengan derajat kepercayaan 95\% atau koefisien sebesar 0,05. Mengacu pada $r$ tabel dengan sampel yang digunakan sebanyak 65, maka $r$ tabel diketahui sebesar 0,206. Jika mengacu pada tabel interpretasi Guilford, $r$ hitung sebesar 0,170 termasuk dalam kategori hubungan yang sangat rendah. Sehingga dapat disimpulkan bahwasannya $\mathrm{r}$ hitung $<\mathrm{r}$ tabel, kemampuan teknis memiliki hubungan yang sangat rendah dengan kualitas pemanfaatan e-resources.

Kemampuan teknis merupakan kemampuan dalam menggunakan media internet khususnya media sosial, di mana seseorang dapat mengakses dan mengoperasikan media sosial secara tepat (Muttaqin, 2015). Kemampuan teknis dalam menggunakan internet terbagi menjadi dua menurut European Commission, (2009) yaitu: computer and internet based skill dimana hanya mampu menggunakan komputer dan internet dengan fitur-fitur utama saja dan advanced internet use yang 
merupakan tingkat kemampuan lanjut dari kemampuan teknis komputer dan internet. Berdasarkan hasil penelitian ini, menunjukan bahwa pustakawan memenuhi kemampuan teknis dan mampu menggunakan internet secara advanced.

\section{Hubungan Kemampuan Kognitif dengan Kualitas Pemanfaatan E-Resources}

Nilai $\mathrm{r}$ hitung diketahui sebesar 0,694 dengan derajat kepercayaan 95\% atau koefisien sebesar 0,05. Mengacu pada $\mathrm{r}$ tabel dengan sampel yang digunakan sebanyak 65, maka $\mathrm{r}$ tabel diketahui sebesar 0,206. Jika mengacu pada tabel interpretasi Guilford, $r$ hitung sebesar 0,694 termasuk dalam kategori hubungan yang cukup kuat. Sehingga dapat disimpulkan bahwasannya $\mathrm{r}$ hitung > $\mathrm{r}$ tabel, kemampuan kognitif memiliki hubungan yang cukup kuat dengan kualitas pemanfaatan e-resources.

Kemampuan kognitif merupakan kemampuan dalam menggunakan media seperti kemampuan memahami, menganalisis, dan mengevaluasi konten media sosial secara komprehensif (European Commission, 2009). Lebih lanjut, masih dari sumber yang sama, kemampuan kognitif ini terbagi dalam tiga aspek, yaitu: understanding media content and its functioning, dimana individu dapat memahami pesan yang disampaikan oleh media, pengetahuan tentang regulasi media (knowledge about media and media regulation), merupakan pengetahuan tentang undang-undang yang menekankan kesadaran terhadap peraturan dan fungsi dari media serta aspek yang ketiga adalah perilaku menggunakan media dapat memberikan wawasan dalam menyikapi media seperti pengecekan informasi baru dan juga tampilan identitas dalam akun media sosial. Berdasarkan hasil penelitian ini, pustakawan telah memenuhi aspek kognitif dalam menggunakan media sosial, mencakup pemahaman akan informasi, regulasi serta kemampuan untuk mengecek kembali informasi yang di dapatkan.

\section{Hubungan Kemampuan Afektif dengan Kualitas Pemanfaatan E-Resources}

Nilai $\mathrm{r}$ hitung diketahui sebesar 0,594 dengan derajat kepercayaan 95\% atau koefisien sebesar 0,05. Mengacu pada $\mathrm{r}$ tabel dengan sampel yang digunakan sebanyak 65, maka $\mathrm{r}$ tabel diketahui sebesar 0,206. Jika mengacu pada tabel interpretasi Guilford, $r$ hitung sebesar 0,594 termasuk dalam kategori hubungan yang cukup kuat. Sehingga dapat disimpulkan bahwasannya $\mathrm{r}$ hitung > $\mathrm{r}$ tabel, kemampuan afektif memiliki hubungan yang cukup kuat dengan kualitas pemanfaatan e-resources.

Kemampuan afektif merupakan kemampuan yang berkaitan dengan sikap dan nilai. Kemampuan afektif mencakup watak perilaku seperti perasaan, minat, sikap, emosi, dan nilai. Lebih lanjut menurut European Commission, (2009) Kemampuan tersebut dapat di lihat dari pemanfaatan media sosial seperti chatting, berkomentar maupun menulis status. Terdapat dua kategori pengguna media sosial, yaitu sebagai partisipan dan content creator. Berdasarkan hasil penelitian ini, pustakawan lebih cenderung menggunakan media sosial sebagai partisipan.

4. Hubungan literasi media sosial dengan pemahaman kemutakhiran informasi (currency)

Nilai $r$ hitung diketahui sebesar 0,514 dengan derajat kepercayaan 95\% atau koefisien sebesar 0,05. Mengacu pada $\mathrm{r}$ tabel dengan sampel yang digunakan sebanyak 65, maka $\mathrm{r}$ tabel diketahui sebesar 0,206. Jika mengacu pada tabel interpretasi Guilford, $r$ hitung sebesar 0,514 termasuk dalam kategori hubungan yang cukup kuat. Sehingga dapat disimpulkan bahwasannya $r$ hitung > $r$ tabel, literasi media sosial memiliki hubungan yang cukup kuat dengan pemahaman kemutakhiran informasi. Kemutakhiran informasi yang relevan digunakan sebagai sumber informasi adalah sekitar 0-5 tahun terakhir (Hermanto, 2004). Artinya, semakin mutakhir informasi tersebut, informasi yang dikandungnya semakin relevan.

5. Hubungan literasi media sosial dengan pemahaman kesesuaian informasi (relevancy)

Nilai $r$ hitung diketahui sebesar 0,576 dengan derajat kepercayaan 95\% atau koefisien sebesar 0,05. Mengacu pada $r$ tabel dengan sampel yang digunakan sebanyak 65, maka $r$ tabel diketahui sebesar 0,206. Jika mengacu pada tabel interpretasi Guilford, $r$ hitung sebesar 0,576 
termasuk dalam kategori hubungan yang cukup kuat. Sehingga dapat disimpulkan bahwasannya $r$ hitung > $r$ tabel, literasi media sosial memiliki hubungan yang cukup kuat dengan pemahaman kesesuaian informasi.

Salah satu tugas pustakawan perguruan tinggi adalah sebagai pustakawan referensi. Pustakawan referensi berperan untuk menemukan informasi dari sumber-sumber referensi seperti e-resources kepada pemustaka. Responden dalam penelitian ini selalu mengutamakan kebermanfaatan informasi yang didapatkan sebagaimana informasi yang dibutuhkan oleh pemustaka. Guna mengetahui keseuaian informasi yang didapatkan, pustakawan dapat mengkonfirmasi terlebih dahulu kepada pemustaka mengenai hal tersebut. Feedback dari pemustaka dapat mengaskan kesesuaian informasi tersebut.

6. Hubungan literasi media sosial dengan pemahaman kepemilikan informasi (authority)

Nilai $\mathrm{r}$ hitung diketahui sebesar 0,546 dengan derajat kepercayaan 95\% atau koefisien sebesar 0,05. Mengacu pada $\mathrm{r}$ tabel dengan sampel yang digunakan sebanyak 65, maka $\mathrm{r}$ tabel diketahui sebesar 0,206. Jika mengacu pada tabel interpretasi Guilford, $r$ hitung sebesar 0,546 termasuk dalam kategori hubungan yang cukup kuat. Sehingga dapat disimpulkan bahwasannya $r$ hitung > $r$ tabel, literasi media sosial memiliki hubungan yang cukup kuat dengan pemahaman kepemilikan informasi.

Pada umumnya responden dalam penelitian ini telah mengetahui pentingnya pemahaman mengenai kepemilikan sumber informasi, hal tersebut ditunjukkan dengan keseharian mereka yang telah terbiasa mencantumkan sumber informasi yang mereka kutip atau dijadikan rujukan. Begitu pula dalam menggunakan informasi, responden cenderung mempertimbangkan afiliasi, keseuaian bidang ilmu penulis serta kontak yang dicantumkan. Sehingga dapat disimpulkan bahwasannya responden memiliki pemahaman tentang kepemilikan sumber informasi (authority) yang baik.

7. Hubungan literasi media sosial dengan pemahaman ketepatan informasi (accuracy)

Nilai $\mathrm{r}$ hitung diketahui sebesar 0,645 dengan derajat kepercayaan 95\% atau koefisien sebesar 0,05. Mengacu pada $\mathrm{r}$ tabel dengan sampel yang digunakan sebanyak 65, maka $\mathrm{r}$ tabel diketahui sebesar 0,206. Jika mengacu pada tabel interpretasi Guilford, $r$ hitung sebesar 0,645 termasuk dalam kategori hubungan yang cukup kuat. Sehingga dapat disimpulkan bahwasannya $r$ hitung > $\mathrm{r}$ tabel, literasi media sosial memiliki hubungan yang cukup kuat dengan pemahaman ketepatan informasi.

Secara umum responden dalam penelitian ini menggunakan informasi dalam e-resources jika jelas mencantumkan sumbernya. Selain itu, responden cukup mempertimbangkan apabila terdapat pihak lain yang merekomendasikan sumber informasi tersebut. Hal tersebut mendukung peran pustakawan sebagai gerbang penyaring informasi. Kemampuan literasi pustakawan memiliki hubungan untuk menghasilkan ketepatan informasi yang dibutuhkan pemustaka.

8. Hubungan literasi media sosial dengan pemahaman alasan publikasi informasi (purpose)

Nilai $r$ hitung diketahui sebesar 0,562 dengan derajat kepercayaan 95\% atau koefisien sebesar 0,05. Mengacu pada $r$ tabel dengan sampel yang digunakan sebanyak 65, maka $r$ tabel diketahui sebesar 0,206. Jika mengacu pada tabel interpretasi Guilford, $r$ hitung sebesar 0,562 termasuk dalam kategori hubungan yang cukup kuat. Sehingga dapat disimpulkan bahwasannya $r$ hitung > r tabel, literasi media sosial memiliki hubungan yang cukup kuat dengan pemahaman alasan publikasi informasi.

Responden dalam penelitian ini secara umum melakukan pertimbangan tujuan informasi tersebut di publikasikan. Selain itu, responden juga mempertimbangkan sudut pandang informasi yang tersedia apakah relevan dengan kebutuhan informasi pemustaka. Memahami alasan publikasi informasi menjadi penting untuk mengetahui netralitas informasi tersebut. Sehingga dapat menjadi sesuai dengan informasi yang dibutuhkan pemustaka. 


\section{SIMPULAN}

Berdasarkan hasil analisis dan pembahasan dalam penelitian ini dapat dilihat hampir keseluruhan variabel $\mathrm{X}$, literasi media sosial, yaitu kemampuan kognitif dan kemampuan afektif memiliki hubungan yang cukup kuat dengan variabel $\mathrm{Y}$, yaitu kualitas pemanfaatan e-reosurces. Meskipun varibel kemampuan teknis hanya memiliki hubungan yang sangat lemah dengan variabel kualitas pemanfaatan e-reosurces. Begitu pula dengan sebaliknya, keseluruhan variabel Y, yaitu kualitas pemanfaatan e-reosurces mencakup aspek pemahaman kemutakhiran informasi (currency), pemahaman kesesuaian informasi (relevancy), pemahaman kepemilikan informasi (authority), pemahaman ketepatan informasi (accuracy) dan yang terakhir adalah pemahaman alasan publikasi informasi (purpose) memiliki hubungan yang cukup kuat dengan variabel $\mathrm{X}$, yaitu literasi sosial media. Secara keseluruhan hubungan variabel $\mathrm{X}$, literasi media sosial dengan variabel Y, kualitas pemanfaatan e-resources berada pada nilai 0,684 yang artinya kedua variabel tersebut memiliki hubungan yang cukup kuat. Sehingga, dapat disimpulkan bahwasannya H0 dalam penelitian ini yaitu adanya hubungan literasi media sosial dengan kualitas pemanfaatan eresources diterima dan $\mathrm{H} 1$ yang mana tidak adanya hubungan literasi media sosial dengan kualitas pemanfaatan e-resources ditolak.

\section{DAFTAR PUSTAKA}

Aljawiy, A. Y. dan Muklason, A. (2012). Jejaring Sosial dan Dampaknya bagi Penggunanya. TEKNOLOGI: Jurnal Ilmiah Sistem Informasi Vol. 1, No. 1, 2011. DOI: https://doi.org/10.26594/teknologi.v1i1.46 Retrieved from http://www.journal.unipdu.ac.id/index.php/teknologi/article/download/46/286.

Arikunto, S. (2010). Prosedur Penelitian Suatu Pendekatan Praktik. Jakarta: Rineka Cipta

European Commission. (2009). Study on Assessment Criteria for Media Literacy Levels. Brussels.

Gumilar, G., Adiprasetio, Justio, and Maharani, N. (2017). Literasi Media: Cerdas Menggunakan Media Sosial Dalam Menanggulangi Berita Palsu (Hoax) Oleh Siswa SMA. Jurnal Pengabdian Kepada Masyarakat Vol. 1, No. 1, Februari 2017: 35 - 40.

Hermanto. (2004). Kajian Kemutakhiran Referensi Artikel Ilmiah Pada Beberapa Jurnal Ilmiah Penelitian Pertanian. Jurnal Perpustakaan Pertanian, Volume 13, (1): 1-6.

Kurnia, N. D., Johan, R.C., dan Rullyana, G. (2018). Hubungan Pemanfaatan Media Sosial Instagram Dengan Kemampuan Literasi Media di UPT Perpustakaan Itenas. Jurnal Edulib Tahun 8, Volume 8 No. 1 Mei 2018.

Meriam Library. (2010). "Evaluating Information-Applying the CRAAP Test" 17 Sept. 2010. Meriam Lib., California State University-Chico. CSU-Chico ReSEARCH Station. Retrieved from https://www.csuchico.edu/lins/handouts/eval websites.pdf.

Muttaqin, M. Z. (2015). Kemampuan Literasi Media (Media Literacy) di Kalangan Remaja Rural Di Kabupaten Lamongan. Retrieved from journal.unair.ac.id/download-fullpapers$\underline{\ln 8 \mathrm{~b} 2 \mathrm{e} 03 \mathrm{a} 1 \mathrm{eafull} . \mathrm{pdf} .}$

Nath, St, A. (2015). Big data Security Issues and Challenges, (August).

Nurjanah, E., Rusmana, A., Yanto, A. (2017). Hubungan Literasi Digital Dengan Kualitas Penggunaan E-Resources. Lentera Pustaka 3 (2): 117-140, 2017. 
Nurmalia, I., Kustiyo, A., Sulistyo-Basuki. (2016). Evaluasi Penggunaan Layanan Koleksi Eresources Menggunakan Standar Indikator Kinerja (ISO 11620:2014) di Perpustakaan Nasional RI. Jurnal Pustakawan Indonesia, Vo. 15 No. 1-2, 2016.

Perpustakaan Nasional. (2018). Jumlah Pustakawan di Indonesia. [Online]. Retrieved from www.pustakawan.perpusnas.go.id.

Rachman, R. A. (2017). Analisis Kompetensi Pustakawan Dalam Memberikan Layanan Informasi (Studi Pada Layanan Referensi Perpustakaan Universitas Brawijaya Malang). Malang: Universitas Brawijaya.

Roosita, N. H. (2012). Uji Asumsi Klasik. Retrieved from https://extraordinarynad.lecturer.ub.ac.id/2012/12/uji-asumsi-klasik/.

Sunyoto, D. (2007). Analisis Korelasi dan Bivariat: Ringkasan dan Kasus. Yogyakarta: Amara Books.

Van Deursen, A \& van Dijk, J. (2009). Improving Digital Skills For The Use Of Online Public Information And Services. Government Information Quarterly 26: 333-340.

Vanwynsberghe, H. \& Verdegem, P. (2013). Integrating Social Media In Education. ClCWebComparative Literature and Culture 15 (3).

Vanwynsberghe, H., Vanderlinde, R., Georges, A., \& Verdegem, P. (2015). The librarian 2.0: Identifying a typology of librarians' social media literacy. https://doi.org/10.1177/0961000613520027.

Yusup, P. M., \& Subekti, P. (2010). Teori dan Praktik Penelusuran Informasi: Information Retrieval. 
Lentera Pustaka: Jurnal Kajian Ilmu Perpustakaan, Informasi dan Kearsipan, 6 (1) 2020, 1-12 